\title{
DNA Relatedness among Erysipelothrix rhusiopathiae Strains Representing All Twenty-Three Serovars and Erysipelothrix tonsillarum
}

\author{
TOSHIO TAKAHASHI, ${ }^{1 *}$ TOMOHIKO FUJISAWA, ${ }^{2}$ YUTAKA TAMURA, ${ }^{1}$ SHOKO SUZUKI, ${ }^{1}$ \\ MASATAKE MURAMATSU, ${ }^{1}$ TAKUO SAWADA, ${ }^{3}$ YOSHIMI BENNO, ${ }^{4}$ AND \\ TOMOTARI MITSUOKA ${ }^{2,3}$
}

National Veterinary Assay Laboratory, Kokubunji, Tokyo $185,{ }^{1}$ Frontier Research Program, RIKEN, Wako, Saitama 351-01, ${ }^{2}$ Nippon Veterinary and Animal Science University, Musashino, Tokyo $180,{ }^{3}$ and Japan Collection of Microorganisms, RIKEN, Wako, Saitama, 351-01, ${ }^{4}$ Japan

\begin{abstract}
The levels of relatedness among strains of Erysipelothrix rhusiopathiae (serovars 1 through 23 and type $\mathbf{N}$ ) were estimated by performing DNA-DNA hybridization experiments with the type strains of $E$. rhusiopathiae and Erysipelothrix tonsillarum, which are the two Erysipelothrix species that have been described. Two distinct DNA relatedness groups were identified. The group 1 strains, representing serovars $1,2,4$ through $6,8,9,11$, 12,15 through 17,19 , and 21 and type $N$, exhibited more than $73 \%$ hybridization with the type strain of $E$. rhusiopathiae but less than $24 \%$ hybridization with the type strain of $E$. tonsillarum. Group 2 included serovar $3,7,10,14,20,22$, and 23 strains, and these strains exhibited more than $66 \%$ hybridization with the type strain of $E$. tonsillarum but less than $27 \%$ hybridization with the type strain of $E$. rhusiopathiae. Strains representing serovars 13 and 18 exhibited low levels of hybridization $(16$ to $47 \%)$ with both of the type strains, indicating that these serovars may be members of a new genomic species. The members of the $E$. rhusiopathiae and $E$. tonsillarum groups resembled each other in many phenotypic characteristics, but differed in their ability to produce acid from saccharose and in their pathogenicity for swine. Our results confirm that the genus Erysipelothrix contains two main genomic species, $E$. rhusiopathiae and $E$. tonsillarum, which can be differentiated into serovars.
\end{abstract}

Erysipelothrix rhusiopathiae is an organism which has a major economic impact, causing a variety of diseases in animals and birds (ranging from septicemia to urticaria), as well as erysipeloid, a skin disease of humans (23). This organism has also been isolated from the tonsils of apparently healthy slaughter swine, from slime on fish, and from the environment. At the present time, the strains of $E$. rhusiopathiae are classified into 23 serovars and the type $\mathrm{N}$ strains, which do not produce any precipitating antibody against homologous and heterologous heat-stable extracts in rabbits $(9,17)$. Heat-stable antigens that are derived from cells by hot aqueous extraction are the basis for dividing the species into serovars (3).

Most isolates obtained from diseased swine belong to serovars 1 and 2 (22), and the genus Erysipelothrix was once thought to be monospecific (12).

A cluster of avirulent serovar 7 strains that were isolated from porcine tonsils were found to be genetically distinct from the other $E$. rhusiopathiae strains. We have previously described these strains as new species, Erysipelothrix tonsillarum $(13,14)$. However, whether genotypic E. tonsillarum strains occur in serovars other than serovar 7 is still unclear. The purposes of this study were to examine the levels of relatedness among organisms belonging to serovars 1 through 23 and type $\mathrm{N}$ by performing DNA-DNA hybridization experiments with the type strains of $E$. rhusiopathiae and $E$. tonsillarum and to clarify the taxonomic relationships among these serovars and the species in the genus Erysipelothrix.

\footnotetext{
* Corresponding author.
}

\section{MATERIALS AND METHODS}

Bacterial strains. Details concerning the test strains and their sources are shown in Table 1 . The strains were maintained on Bacto Stock Culture Agar (Difco Laboratories, Detroit, Mich.).

Cultural and biochemical tests. The strains were characterized biochemically by using the tests listed in Table 2 . The production of $\mathrm{H}_{2} \mathrm{~S}$ was tested in triple sugar iron agar (Difco). Cytochrome oxidase test strips (Eiken Chemical Co., Ltd, Tokyo, Japan) were used to detect the presence of this enzyme. Plasma-clotting activity was detected by mixing a 24-h broth culture with fresh citrated rabbit plasma (19). All of the other biochemical test procedures which we used have been described previously (21). The medium used to test for production of acid from carbohydrates was nutrient broth supplemented with $1 \%$ Andrades indicator and $10 \%$ horse serum (20). Antibiotic susceptibility was tested by using an agar dilution method (15).

Test used to determine serovars. The serotypes of the strains were determined by using a previously described method $(5,6,17)$. Colonies from a 48-h agar plate of each strain were inoculated into beef infusion (BI) broth $(\mathrm{pH} 7.6$; prepared in our laboratory) containing $0.1 \%$ Tween 80 . After incubation for $48 \mathrm{~h}$ at $37^{\circ} \mathrm{C}$, the broth culture was centrifuged at $12,000 \times g$ for $20 \mathrm{~min}$. The bacterial cells were washed three times with physiological saline and suspended in distilled water to $1 / 30$ of the original volume. The bacterial suspension was autoclaved for $1 \mathrm{~h}$ at $121^{\circ} \mathrm{C}$, cooled, and clarified by centrifugation. The supernatant fluid was tested by using an agar gel double-diffusion precipitation system against typing sera (rabbit origin) representing serovars 1 through 23 and type $\mathrm{N}$ of $E$. rhusiopathiae.

Pathogenicity tests. For pathogenicity tests, we used 
TABLE 1. Serovars, origins, and levels of pathogenicity of E. rhusiopathiae and E. tonsillarum strains used in this study

\begin{tabular}{|c|c|c|c|c|c|}
\hline \multirow[b]{2}{*}{ Strain } & \multirow[b]{2}{*}{$\begin{array}{l}\text { Serovar } \\
\text { or type }\end{array}$} & \multirow[b]{2}{*}{ Origin $^{a}$} & \multirow[b]{2}{*}{$\begin{array}{l}\text { Pathogenicity for mice } \\
\qquad\left(\log \mathrm{LD}_{50}\right)^{b}\end{array}$} & \multicolumn{2}{|c|}{ Pathogenicity for swine } \\
\hline & & & & $\begin{array}{l}\text { Size of erythema }{ }^{c} \\
(\mathrm{~cm})^{c}\end{array}$ & Systemic $^{d}$ \\
\hline \multicolumn{6}{|c|}{ E. rhusiopathiae strains } \\
\hline ATCC $19414^{\mathrm{T}}$ & 2 & Pig with endocarditis & 0.3 & Generalized & + \\
\hline ME-7 & $1 \mathrm{a}$ & Unknown & 1.0 & Generalized & + \\
\hline Sayo-SP & $1 \mathrm{a}$ & Chicken & 1.1 & Generalized & + \\
\hline $422 / 1 \mathrm{E} 1$ & $1 b$ & Porcine spleen & 1.0 & Generalized & + \\
\hline R32E11 & 2 & Unknown & 1.5 & Generalized & + \\
\hline NF4E1 & 2 & Porcine spleen & 1.3 & Generalized & + \\
\hline Witlling & 3 & Fish & 0.5 & & - \\
\hline Doggerscharbe & 4 & Fish & $>7.0$ & & - \\
\hline Pécs 67 & 5 & Porcine tonsil & 1.4 & 15 by 17 & - \\
\hline Dolphin S-1 & 5 & Dolphin & 2.2 & & - \\
\hline Tuzok & 6 & Bustard & 0.8 & & - \\
\hline Dolphin E-1 & 6 & Dolphin & 0.4 & & - \\
\hline Goda & 8 & Godwit & 0.6 & 10 by 10 & - \\
\hline Kaparek & 9 & Fish & $>6.9$ & & - \\
\hline Lengyel-P & 10 & Squirrel & 0.2 & & - \\
\hline IV $12 / 8$ & 11 & Porcine tonsil & 0.9 & 16 by 17 & - \\
\hline Pécs 9 & 12 & Porcine tonsil & 0.7 & Generalized & + \\
\hline Pécs 56 & 13 & Porcine tonsil & $>6.5$ & & - \\
\hline Iszap-4 & 14 & Mud of zoo pond & 0.8 & & - \\
\hline Pécs 3597 & 15 & Porcine tonsil & 1.2 & & - \\
\hline Tanzania & 16 & Parrot & 1.4 & & - \\
\hline 545 & 17 & Porcine spleen & $>6.5$ & & - \\
\hline 715 & 18 & Porcine spleen & 1.1 & 18 by 20 & - \\
\hline 2017 & 19 & Porcine spleen & 0.9 & 12 by 16 & - \\
\hline 2553 & 20 & Porcine spleen & 1.5 & 10 by 12 & - \\
\hline Bãno 36 & 21 & Sheep dip & 0.8 & 14 by 18 & - \\
\hline Bãno 107 & 22 & Sheep dip & $>5.9$ & & - \\
\hline $\mathrm{KS} 20 \mathrm{~A}$ & 23 & Pig slurry & 1.4 & & - \\
\hline MEW 22 & $\mathbf{N}$ & Unknown & 1.0 & & - \\
\hline \multicolumn{6}{|c|}{ E. tonsillarum strains } \\
\hline ATCC $43339^{T}$ & 7 & Porcine tonsil & $>5.3$ & & - \\
\hline ATCC 43338 & 7 & Porcine tonsil & $>5.8$ & & - \\
\hline P-43 & 7 & Fish & 1.8 & & - \\
\hline L1-3 & 7 & Chopped pork & 0.9 & & - \\
\hline L1-4 & 7 & Chopped pork & 0.8 & & - \\
\hline Nairiku-21 & 7 & Porcine lymph node & 0.8 & & - \\
\hline NG-37 & 7 & Pig slurry & 1.0 & & - \\
\hline $\mathrm{T}-131$ & 7 & Porcine tonsil & 1.2 & & - \\
\hline
\end{tabular}

${ }^{a}$ Strains ATCC $19414^{\mathrm{T}}\left(\mathrm{T}=\right.$ type strain), ATCC $43339^{\mathrm{T}}$, and ATCC 43338 were received from the American Type Culture Collection, Rockville, Md. Strains Sayo-SP, Dolphin S-1, Dolphin E-1, L1-3, L1-4, Nairiku-21, and NG-37 were preserved in our laboratory. The other strains, including the serovar reference strains representing serovars 1 through 23 and type N, were provided by K. Hashimoto, National Institute of Animal Health, Tokyo, Japan, R. L. Wood, National Animal Disease Center, Ames, Iowa, and V. Nørrung, State Veterinary Serum Laboratory, Copenhagen, Denmark.

${ }^{b}$ Mice were inoculated subcutaneously with serial dilutions of a broth culture of each strain. The $\mathrm{LD}_{50}$ values are expressed as the numbers of viable bacteria per mouse.

${ }^{c}$ Maximum size of erythema at the skin injection site, which was observed for 2 weeks after intradermal inoculation with $0.1 \mathrm{ml}$ of a broth culture (approximately $10^{7} \mathrm{CFU}$ ) of each strain.

+ , depression and anorexia; - , no response.

4-week-old female outbred strain ddY mice (Nippon SLC Co., Ltd., Hammatsu, Japan).

Female and castrated male Yorkshire swine, which were purchased from the Minano Agricultural Cooperative Association for Laboratory Animals, Saitama, Japan, were used when they were 3 to 4 months old. These swine were conventionally farrowed and raised in confinement. The sera of the swine had growth agglutination titers (11) of $<1: 8$.

The levels of strain pathogenicity for mice and swine were determined by using a previously described method $(16,18)$. A portion $(0.1 \mathrm{ml})$ of one of a series of 10 -fold dilutions of a BI broth culture of each strain was injected subcutaneously into each of five mice. At the same time, $0.1 \mathrm{ml}$ of each dilution was spread onto two petri plates and mixed with $\mathrm{BI}$ agar medium containing $0.75 \%$ agar. After $48 \mathrm{~h}$ of cultivation at $37^{\circ} \mathrm{C}$, the colonies in the agar were counted. To determine the $50 \%$ lethal doses $\left(\mathrm{LD}_{50}\right)$, mortality rates were recorded 14 days after exposure. The $\mathrm{LD}_{50}$ values were determined by using the method of Kärber (4).

One pig was inoculated intradermally with $0.1 \mathrm{ml}$ of a BI broth culture (approximately $10^{7} \mathrm{CFU}$ per pig) of each strain. Clinical signs were observed every day for 14 days after exposure.

Preparation of DNA. To prepare DNA, bacterial cells grown in $\mathrm{BI}$ broth containing $0.1 \%$ Tween 80 were harvested in the logarithmic phase and were washed twice with $0.15 \mathrm{M}$ $\mathrm{NaCl}-0.1 \mathrm{M}$ EDTA ( $\mathrm{pH} 8.0$ ). The DNA was isolated by using a modification of the procedure of Marmur (7). The purity and the amount of DNA were estimated by measuring the hyperchromic shift during thermal denaturation (1). 
TABLE 2. Differential phenotypic characteristics of Erysipelothrix species

\begin{tabular}{|c|c|c|c|}
\hline \multirow[b]{2}{*}{ Characteristic } & \multicolumn{3}{|c|}{$\%$ of strains having a positive reaction } \\
\hline & $\begin{array}{l}\text { E. rhusiopathiae } \\
\text { (21 strains) }\end{array}$ & $\begin{array}{l}\text { E. tonsillarum } \\
\text { (14 strains) }\end{array}$ & $\begin{array}{l}\text { Others } \\
\text { (2 strains) }\end{array}$ \\
\hline $\begin{array}{l}\mathrm{H}_{2} \mathrm{~S} \text { production (triple } \\
\text { sugar iron agar) }\end{array}$ & 100 & 100 & 100 \\
\hline Test tube brush in gelatin & 100 & 100 & 100 \\
\hline Catalase activity & 0 & 0 & 0 \\
\hline Oxidase activity & 0 & 0 & 0 \\
\hline \multicolumn{4}{|l|}{ Acid produced from: } \\
\hline Saccharose & 0 & 93 & 0 \\
\hline Glycerol & 0 & 0 & 0 \\
\hline Maltose & 100 & 100 & 100 \\
\hline Salicin & 0 & 14 & 50 \\
\hline Inosite & 0 & 0 & 0 \\
\hline Galactose & 100 & 100 & 50 \\
\hline Levulose & 100 & 100 & 100 \\
\hline Dulcitol & 0 & 0 & 0 \\
\hline Rhaffinose & 0 & 0 & 0 \\
\hline Mannite & $\mathbf{0}$ & 0 & 0 \\
\hline Mannose & 100 & 43 & 100 \\
\hline Lactose & 100 & 100 & 50 \\
\hline Glucose & 100 & 100 & 100 \\
\hline Rhamnose & 0 & 0 & 0 \\
\hline Trehalose & 0 & 0 & 50 \\
\hline Inulin & 0 & 0 & 0 \\
\hline Xylose & 0 & 0 & 0 \\
\hline Sorbitol & 0 & 0 & 0 \\
\hline Arabinose & 0 & 0 & 0 \\
\hline Clotting of citrated plasma & 100 & 100 & 100 \\
\hline \multicolumn{4}{|l|}{ Susceptibility to: } \\
\hline Penicillin G $(0.1 \mathrm{U} / \mathrm{ml})$ & 100 & 100 & 100 \\
\hline Ampicillin $(0.1 \mu \mathrm{g} / \mathrm{ml})$ & 100 & 100 & 100 \\
\hline Kanamycin $(100 \mu \mathrm{g} / \mathrm{ml})$ & 0 & 0 & 0 \\
\hline $\begin{array}{l}\text { Sulfadimethoxine (100 } \\
\mu \mathrm{g} / \mathrm{ml})\end{array}$ & 0 & 0 & 0 \\
\hline \multicolumn{4}{|l|}{ Pathogenicity for swine: } \\
\hline Generalized erythema ${ }^{a}$ & 33 & 0 & $\mathbf{0}$ \\
\hline Localized erythema $^{b}$ & 24 & 7 & 50 \\
\hline No clinical signs ${ }^{c}$ & 43 & 93 & 50 \\
\hline
\end{tabular}

Tritium-labeled DNA was prepared by using a nick translation system (New England Nuclear Corp., Boston, Mass.) adapted from the procedure of Rigby et al. (10).

DNA base composition. The guanine-plus-cytosine contents of DNAs were determined by the thermal melting point method (8), using an automatic recording spectrophotometer (Komatsu Electronics, Tokyo, Japan). Calf thymus DNA was included in each set as a standard.

DNA homology experiments. DNA homology experiments were performed by using the S1 nuclease procedure, as described by Johnson et al. (2). S1 nuclease digestion was performed with $0.5 \mathrm{U}$ of S1 nuclease (Seikagaku Kogyo Co., Tokyo, Japan). After incubation for $15 \mathrm{~min}$ at $37^{\circ} \mathrm{C}$, an equal volume of $10 \%$ trichloroacetic acid was added to each tube. The tubes were cooled to $4^{\circ} \mathrm{C}$ for at least $1 \mathrm{~h}$, and the precipitates were collected on nitrocellulose membrane filters (type HA; Millipore Corp., Bedford Mass.). The membranes were dried, and the radioactivity was measured in a toluene-based scintillation fluid with a model 3330 liquid scintillation counter (Packard Instrument Co., Inc., Rockville, Md.).
TABLE 3. Levels of DNA relatedness among E. rhusiopathiae and $E$. tonsillarum strains

\begin{tabular}{|c|c|c|c|c|}
\hline \multirow{2}{*}{ Strain } & \multirow{2}{*}{$\begin{array}{l}\text { Serovar } \\
\text { or type }\end{array}$} & \multirow{2}{*}{$\begin{array}{l}\text { Guanine-plus- } \\
\text { cytosine } \\
\text { content of } \\
\text { DNA (mol\%) }\end{array}$} & \multicolumn{2}{|c|}{$\begin{array}{c}\% \text { Homology } \\
\text { with }\left[{ }^{3} \mathrm{H}\right] \mathrm{DNA} \\
\text { from: }\end{array}$} \\
\hline & & & $\begin{array}{l}\text { Strain } \\
\text { ATCC } \\
19414^{\mathrm{T}}\end{array}$ & $\begin{array}{l}\text { Strain } \\
\text { ATCC } \\
43339^{\mathrm{T}}\end{array}$ \\
\hline \multicolumn{5}{|c|}{ E. rhusiopathiae strains } \\
\hline ATCC $19414^{\mathrm{T}}$ & 2 & 38 & 100 & 16 \\
\hline ME-7 & $1 \mathrm{a}$ & 36 & 89 & 14 \\
\hline Sayo-SP & 1a & 37 & 97 & 16 \\
\hline $422 / 1 \mathrm{E} 1$ & $1 \mathrm{~b}$ & 37 & 92 & 24 \\
\hline R32E11 & 2 & 40 & 97 & 18 \\
\hline NF4E1 & 2 & 37 & 102 & 17 \\
\hline Doggerscharbe & 4 & 36 & 76 & 17 \\
\hline Pécs 67 & 5 & 39 & 99 & 21 \\
\hline Dolphin S-1 & 5 & 37 & 86 & 21 \\
\hline Tuzok & 6 & 37 & 73 & 20 \\
\hline Dolphin E-1 & 6 & 37 & 77 & 17 \\
\hline Goda & 8 & 36 & 101 & 18 \\
\hline Kaparek & 9 & 37 & 95 & 17 \\
\hline IV12/8 & 11 & 36 & 89 & 15 \\
\hline Pécs 9 & 12 & 37 & 87 & 14 \\
\hline Pécs 3597 & 15 & 38 & 86 & 16 \\
\hline Tanzania & 16 & 36 & 103 & 15 \\
\hline 545 & 17 & 37 & 96 & 17 \\
\hline 2017 & 19 & 39 & 91 & 16 \\
\hline Bãno 36 & 21 & 40 & 85 & 17 \\
\hline MEW 22 & $\mathbf{N}$ & 40 & 93 & 21 \\
\hline \multicolumn{5}{|c|}{ E. tonsillarum strains } \\
\hline ATCC $43339^{\mathrm{T}}$ & 7 & 35 & 25 & 100 \\
\hline Witlling & 3 & 37 & 21 & 82 \\
\hline ATCC 43338 & 7 & 37 & 21 & 93 \\
\hline$P-43$ & 7 & 36 & 20 & 87 \\
\hline L1-3 & 7 & 38 & 24 & 82 \\
\hline L1-4 & 7 & 38 & 21 & 79 \\
\hline Nairiku-21 & 7 & 38 & 23 & 66 \\
\hline NG-37 & 7 & 36 & 24 & 77 \\
\hline $\mathrm{T}-131$ & 7 & 37 & 18 & 75 \\
\hline Lengyel-P & 10 & 37 & 26 & 78 \\
\hline Iszap-4 & 14 & 36 & 21 & 80 \\
\hline 2553 & 20 & 36 & 26 & 74 \\
\hline Bãno 107 & 22 & 38 & 27 & 80 \\
\hline KS20A & 23 & 38 & 26 & 81 \\
\hline \multicolumn{5}{|l|}{ Other strains } \\
\hline Pécs 56 & 13 & 35 & 19 & 24 \\
\hline 715 & 18 & 38 & 47 & 16 \\
\hline
\end{tabular}

\section{RESULTS}

The results of the pathogenicity tests are shown in Table 1. In swine, seven strains belonging to serovars 1,2 , and 12 induced generalized urticarial lesions with depression and anorexia after intradermal inoculation. Seven strains belonging to serovars $5,8,11$, and 18 through 21 induced local urticarial lesions at the site of inoculation. The remaining strains, which belonged to serovars $3,4,6,7,10,12$ through 17,22 , and 23 and type $\mathrm{N}$, induced no clinical signs.

Of the 37 strains tested, 30 (belonging to serovars 1 through 3,5 through 8,10 through 12,14 through 16,18 through 21 , and 23 and type $N$ ) were highly virulent for mice $\left(\mathrm{LD}_{50}\right.$ values, $<10^{2.2} \mathrm{CFU}$ ), and the remaining strains had $\mathrm{LD}_{50}$ values of more than $10^{5.9} \mathrm{CFU}$.

The DNA base compositions of the strains tested and the results of the DNA-DNA hybridization experiments are shown in Table 3. The strains had guanine-plus-cytosine contents ranging from 35 to $40 \mathrm{~mol} \%$ but were separated into 
three groups on the basis of the percentages of DNA-DNA reassociation with the type strains of $E$. rhusiopathiae and $E$. tonsillarum. Clearly, the strains belonging to $E$. rhusiopathiae serovars hybridized at levels of $73 \%$ or more with the type strain of that species, and the strains belonging to $E$. tonsillarum serovars hybridized at levels of $66 \%$ or more with the type strain of $E$. tonsillarum. In each case the nonhomologous values were less than $<30 \%$. There was a minor group containing two strains which exhibited minimal association with each type strain.

The differential biochemical and pathogenic characteristics of the Erysipelothrix species are shown in Table 2. Except for the ability to produce acid from saccharose, the biochemical characteristics of the Erysipelothrix species were nearly identical; $13(93 \%)$ of the 14 strains which belonged to $E$. tonsillarum serovars produced acid from saccharose, whereas none of the 21 strains which belonged to E. rhusiopathiae serovars did so. In the pathogenicity tests, $12(57 \%)$ of the 21 strains which belonged to $E$. rhusiopathiae serovars induced generalized or localized erythema in swine after intradermal inoculation, whereas $13(93 \%)$ of the 14 strains which belonged to $E$. tonsillarum serovars did not induce any clinical sign of erysipelas in swine.

\section{DISCUSSION}

In previous study we described a cluster of avirulent serovar 7 strains that were isolated from porcine tonsils and were genetically distinct from the other $E$. rhusiopathiae isolates and suggested that these serovar 7 strains should be transferred to a new species, E. tonsillarum $(13,14)$. In contrast to the original description of $E$. tonsillarum, in this study we found that $E$. tonsillarum strains can be members of several of the serovars (other than serovar 7) formerly associated with $E$. rhusiopathiae. Both $E$. rhusiopathiae and $E$. tonsillarum contain a number of serovars, but none of the strains which we tested is common to both species. $E$. tonsillarum is distinguished from the other species by the fermentation of saccharose and by a lack of pathogenicity for swine, as well as by serology. Therefore, we suggest that the serovar $3,10,14,20,22$, and 23 strains that have been identified phenotypically as $E$. rhusiopathiae previously should be transferred to $E$. tonsillarum along with the serovar 7 strains.

The low DNA relatedness values (16 to $47 \%$ ) between the serovar 13 or 18 strains and the type strains of two genomic species indicate that these minor serovar groups may be members of a new genomic species of the genus Erysipelothrix. However, more strains will have to be collected to support this hypothesis.

The virulence factor of the organisms is not clearly understood. The serovars of the Erysipelothrix species are based on antigenic characteristics of soluble peptidoglycans of the cell wall (3). In this study, we clarified that the serologically distinguished strains which are highly virulent for swine are capable of inducing generalized urticaria lesions with depression and anorexia and can be assigned to the E. rhusiopathiae group. Our results from pathogenicity tests confirmed our previous results $(13,14) ; E$. rhusiopathiae strains are pathogenic for swine, but $E$. tonsillarum strains are not. Our genetic data, in conjunction with differences in some phenotypic properties, confirmed the heterogeneity of the groups of organisms and led to recognition of the two Erysipelothrix species.

On the basis of these findings, we confirmed that the genus Erysipelothrix contains two species, E. rhusiopathiae and $E$. tonsillarum. These species are serologically distinct, belong to separate DNA-DNA hybridization groups, and can be distinguished by whether they ferment saccharose.

\section{REFERENCES}

1. Doty, P., J. Marmur, G. Eligmer, and C. Schildkraut. 1960. Standard separation and specific recombination in deoxyribonucleic acid: physical chemical studies. Proc. Natl. Acad. Sci. USA 46:461-476.

2. Johnson, J. L., C. F. Phelps, C. S. Cummins, J. London, and F. Gasser. 1980. Taxonomy of the Lactobacillus acidophilus group. Int. J. Syst. Bacteriol. 30:53-68.

3. Kalf, G., and T. G. White. 1963. The antigenic components of Erysipelothrix rhusiopathiae. II. Purification and chemical characterization of a type-specific antigen. Arch. Biochem. Biophys. 102:39-47.

4. Kärber, G. 1931. Beitrag zur kollektiven Behandlung pharmakologischer Reihenversuche. Arch. Exp. Pathol. Pharmakol. 162: $480-487$.

5. Kucsera, G. 1972. Comparative study on special serotypes of Erysipelothrix rhusiopathiae isolated in Hungary and abroad. Acta Vet. Acad. Sci. Hung. 22:251-261.

6. Kucsera, G. 1973. Proposal of standardization of the designations used for serotypes of Erysipelothrix rhusiopathiae (Migula) Buchanan. Int. J. Syst. Bacteriol. 23:184-188.

7. Marmur, J. 1961. A procedure for the isolation of deoxyribonucleic acid from micro-organisms. J. Mol. Biol. 3:208-218.

8. Marmur, J., and P. Doty. 1962. Determination of the base composition of deoxyribonucleic acid from its thermal denaturation temperature. J. Mol. Biol. 5:109-118.

9. Nørrung, V., B. Munch, and H. E. Larsen. 1987. Occurrence, isolation and serotyping of Erysipelothrix rhusiopathiae in cattle and pig slurry. Acta Vet. Scand. 28:9-14.

10. Rigby, P. W., M. Dieckmann, C. Rhode, and P. Berg. 1977 Labeling deoxyribonucleic acid to high specific activity in vitro by nick translation with DNA polymerase I. J. Mol. Biol. 113:237-251.

11. Sawada, T., M. Muramatsu, and K. Seto. 1979. Responses of growth agglutinating antibody and protection of pigs inoculated with swine erysipelas live vaccine. J. Vet. Med. Sci. 41:593-600.

12. Seeliger, H. P. R. 1974. Genus Erysipelothrix, p. 597. In R. E. Buchanan and N. E. Gibbons (ed.), Bergey's manual of determinative bacteriology, 8th ed. The Williams \& Wilkins Co., Baltimore.

13. Takahashi, T., T. Fujisawa, Y. Benno, Y. Tamura, T. Sawada, S. Suzuki, M. Muramatsu, and T. Mitsuoka. 1987. Erysipelothrix tonsillarum sp. nov. isolated from tonsils of apparently healthy pigs. Int. J. Syst. Bacteriol. 37:166-168.

14. Takahashi, T., T. Sawada, M. Muramatsu, Y. Tamura, T. Fujisawa, Y. Benno, and T. Mitsuoka. 1987. Serotype, antimicrobial susceptibility, and pathogenicity of Erysipelothrix rhusiopathiae isolates from tonsils of apparently healthy slaughter pigs. J. Clin. Microbiol. 25:536-539.

15. Takahashi, T., T. Sawada, K. Ohmae, N. Terakado, M. Muramatsu, K. Seto, T. Maruyama, and M. Kanzaki. 1984. Antibiotic resistance of Erysipelothrix rhusiopathiae isolated from pigs with chronic swine erysipelas. Antimicrob. Agents Chemother. 25:385-386.

16. Takahashi, T., T. Sawada, K. Seto, M. Muramatsu, T. Maruyama, and M. Kanzaki. 1985. Pathogenicity of Erysipelothrix rhusiopathiae strains of serovars 1a, 3, 5, 6, 8, 11, 21, and type $\mathrm{N}$ isolated from slaughter pigs affected with chronic erysipelas. J. Vet. Med. Sci. 47:1-8.

17. Takahashi, T., T. Sawada, M. Takagi, K. Seto, M. Kanzaki, and T. Maruyama. 1984. Serotypes of Erysipelothrix rhusiopathiae strains isolated from slaughter pigs affected with chronic erysipelas. J. Vet. Med. Sci. 46:149-153.

18. Takahashi, T., M. Takagi, T. Sawada, and K. Seto. 1984. Cross protection in mice and swine immunized with live erysipelas vaccine to challenge exposure with strains of Erysipelothrix rhusiopathiae of various serotypes. Am. J. Vet. Res. 45:21152118.

19. Takahashi, T., I. Takahashi, Y. Tamura, T. Sawada, T. Yoshida, 
S. Suzuki, and M. Muramatsu. 1990. Mechanism of plasma clotting by Erysipelothrix rhusiopathiae. J. Clin. Microbiol. 28:2161-2164.

20. White, T. G., and R. D. Shuman. 1961. Fermentation reactions of Erysipelothrix rhusiopathiae. J. Bacteriol. 82:595-599.

21. Wood, R. L. 1970. Erysipelothrix, p. 101-105. In J. E. Blair, E. H. Lennette, and J. P. Truant (ed.), Manual of clinical microbiology. American Society for Microbiology, Washington, D.C.

22. Wood, R. L. 1984. Swine erysipelas-a review of prevalence and research. J. Am. Vet. Med. Assoc. 184:944-948.

23. Wood, R. L., and R. D. Shuman. 1975. Swine erysipelas, p. 565-620. In H. W. Dunne and A. D. Leman (ed.), Diseases of swine, 4th ed. Iowa State University Press, Ames. 